\title{
THE CHLOROPLATINATE-CHLOROPLATINITE ELECTRODE
}

\author{
By Edgar Reynolds Smith
}

\section{ABSTRACT}

A platinum electrode immersed in tenth normal potassium chloride solution containing a mixture of potassium chloroplatinate and potassium chloroplatinite has a definite electromotive force corresponding to the electrode reaction $\mathrm{PtCl}_{4}{ }^{-}+$ $2 \mathrm{Cl}^{-}=\mathrm{PtCl}_{6}--+2 \mathrm{e}^{-}$. This electromotive force was measured against the tenth normal calomel electrode and extrapolated to pure tenth normal potassium chloride solution. The experimental results show that this electrode functions reversibly.

\section{CONTENTS}

Page

I. Introduction

II. Apparatus

III. Materials

IV. Experimental results _... 738

V. Discussion

VI. Summary

\section{INTRODUCTION}

An investigation by Miller and Terrey ${ }^{1}$ has shown that an inert electrode immersed in a solution containing sodium chloroplatinate and sodium chloroplatinite acquires a definite potential. Their reference electrode was a calomel electrode containing sodium chloride instead of the usual potassium chloride and their cell may be formulated as follows

$$
-\mathrm{Hg}|\mathrm{HgCl}, \mathrm{NaCl}| \mathrm{NaCl}+\mathrm{Na}_{2} \mathrm{PtCl}_{6}+\mathrm{Na}_{2} \mathrm{PtCl}_{4} \mid \mathrm{Pt}+
$$

The cell reaction is

$$
2 \mathrm{Hg}+\mathrm{Na}_{2} \mathrm{PtCl}_{6}=2 \mathrm{HgCl}+\mathrm{Na}_{2} \mathrm{PtCl}_{4}
$$

The electrochemical reaction at the platinum electrode is

$$
\mathrm{PtCl}_{6}{ }^{-}+2 \mathrm{e}^{-}=\mathrm{PtCl}_{4}^{--}+2 \mathrm{Cl}^{-}
$$

Since this electrode represents a new type of chloride ion electrode as compared with the usual forms, such as $\mathrm{Cl}_{2}(\mathrm{~g}), \mathrm{Cl}^{-}, \mathrm{Ag} \mid \mathrm{AgCl}, \mathrm{Cl}^{-}$ and $\mathrm{Hg} \mid \mathrm{HgCl}, \mathrm{Cl}^{-}$, and presents the unusual feature that no change in charge occurs during the oxidation and reduction of the complex platinum ions, some further experimental tests of this electrode may be of interest.

In this work the potassium salts of chloroplatinic and chloroplatinous acid were used and the reference electrode was the calomel half cell with tenth normal potassium chloride solution. Liquid junction potentials were made negligible by using tenth normal potassium chloride as the solvent for the platinum salts and by using only 
relatively small concentrations of the latter, thus maintaining a practically constant thermodynamic environment. ${ }^{2}$ The cell can be written

$$
-\mathrm{Hg}|\mathrm{HgCl}, \mathrm{KCl}(0.1)| \begin{aligned}
& \mathrm{KCl}(0.1) \\
& \mathrm{PtCl}_{4}^{-}-\left\{\begin{array}{c}
\text { small concns. } \\
\text { compared with } \\
\mathrm{PtCl}_{6}-{ }^{2} \text { normal. }
\end{array}\right.
\end{aligned} \mid \mathrm{Pt}+
$$

The expression for its electromotive force is

$$
E=E_{0}-\frac{R T}{2 F} \log _{\ominus} \frac{\left(\mathrm{PtCl}_{4}^{--}\right)}{\left(\mathrm{PtCl}_{6}^{--}\right)}
$$

where the terms in parentheses are the activities of the chloroplatinite and chloroplatinate ions. Since activity coefficients depend on the ionic strength ${ }^{3}$ of the solution, the data obtained were correlated by means of the empirical equation

$$
E=E_{0}-\frac{R T}{2 F} \log _{\ominus} \frac{\left(P t C l_{4}^{--}\right)}{\left(P t C l_{6}^{--}\right)}+k \sqrt{\sigma}
$$

where the terms in parentheses now represent actual concentration and $\sigma$ is the ionic strength of the solution. If we let

$$
E^{\prime}=E+\frac{R T}{2 F} \log _{\mathrm{e}} \frac{\left(\mathrm{PtCl}_{4}^{--}\right)}{\left(\mathrm{PtCl}_{6}^{-{ }^{-}}\right)}
$$

Equation (2) becomes

$$
E^{\prime}=E_{0}+k \sqrt{\sigma}
$$

This equation was tested for the system at $35^{\circ} \mathrm{C}$.

\section{APPARATUS}

The cell is shown in Figure 1. The inert electrode consisted of a piece of lightly platinized platinum gauze 1 by $2.5 \mathrm{~cm}$. The cell was immersed in a thermostat containing well-stirred liquid petrolatum and provided with a mercury contact regulator and a heater. The temperature was held constant at $35^{\circ} \pm 0.05^{\circ}$ as measured with a calibrated thermometer graduated in $0.2^{\circ}$ divisions and read with an attached magnifying glass.

The electromotive force measurements were made with a Leeds \& Northrup type K potentiometer and a certified standard cell.

\section{MATERIALS}

The potassium chloride was prepared by once recrystallizing the "c. p." salt from water. The salt thus obtained was dried and heated to incipient fusion in a platinum dish.

2 Washburn, Principles of Physical Chemistry, McGraw-Hill Book Co., New York; 1915

3 Lewis and Randall, Thermodynamics and the Freo Energy of Chemical Substances, McGraw-Hill Book Co., New York, 1923. 
Calomel was prepared by dissolving purified mercury in cool nitric acid and precipitating with hydrochloric acid. The mercury used was "virgin" mercury which had been thoroughly washed with dilute nitric acid and subsequently twice distilled, first in a Hulett still and then in a vacuum still. The precipitated mercurous chloride was washed free from acid by decantation, filtered by suction, washed repeatedly with tenth normal potassium chloride, and made into a paste with the latter and the purified mercury.

For the preparation of the platinum salts, platinum sponge and a 10 per cent solution of pure chloroplatinic acid were kindly supplied by Dr. E. Wichers of this bureau. The platinum sponge had been purified for use in the preparation of thermoelements and was free of

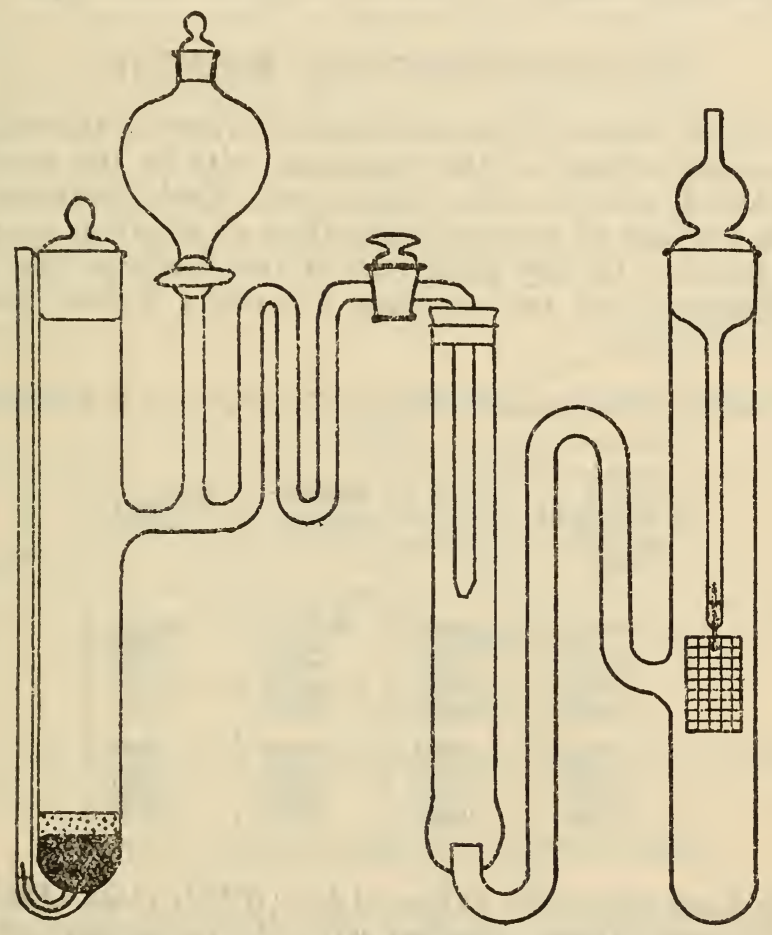

FIGURE 1.-The electrode system

heavy metal impurities as far as could be detected by spectrographic determination. It probably contained small amounts (not over 0.01 per cent) of alkali salts.

For the preparation of the potassium chloroplatinite, platinum sponge was dissolved in aqua regia, the solution evaporated several times with hydrochloric acid to expel nitric acid, and subsequently reduced to chloroplatinous acid by means of sulphur dioxide according to the method of Heraeus ${ }^{4}$ as described by Wöhler and Frey. ${ }^{5}$ The salt obtained by adding potassium chloride was recrystallized first from distilled water, then from hydrochloric acid, and finally 
dried at $80^{\circ}$ to $90^{\circ}$ to constant weight. The platinum content of this salt was determined by precipitating with hydrogen sulphide in acid solution and igniting the precipitated sulphide to metal. The value found was 47.13 per cent as compared with the theoretical value of 47.01 per cent.

The potassium chloroplatinate was prepared from the 10 per cent solution of chloroplatinic acid. This solution was part of a stock solution prepared from platinum sponge, of the same quality as that previously mentioned, by anodic oxidation in concentrated hydrochloric acid. The chloroplatinate was obtained by adding a saturated acidified solution of potassium chloride.

The solutions were prepared by weighing the dry salts and the water, the concentrations being expressed in formula weights per $1,000 \mathrm{~g}$ of water.

\section{EXPERIMENTAL RESULTS}

The measured values of the electromotive force of the cell, together with the concentrations of the platinum salts in the solutions, are shown in Table 1, which is self-explanatory. Each electromotive force value is the average of ten readings taken at intervals over a period of several hours. In any given set of ten readings the maximum difference between any two readings was never greater than $0.2 \mathrm{mv}$ and was usually less.

TABLE 1.-Emf of cell containing $K_{2} \mathrm{PtCl}_{4}$ and $\mathrm{K}_{2} \mathrm{PtCl}_{6}$ in $0.1 \mathrm{M} \mathrm{KCl}$ solution at $35^{\circ}$

\begin{tabular}{|c|c|c|c|}
\hline $\begin{array}{c}\text { Concentra- } \\
\text { tion of } \\
\mathrm{K}_{2} \mathrm{PtCl} \mathrm{Cl}_{4} \text { mole } \\
\text { per } 1,000 \mathrm{~g} \\
\mathrm{H}_{2} \mathrm{O}\end{array}$ & $\begin{array}{c}\text { Concentra- } \\
\text { tion of } \\
\mathrm{K}_{2} \mathrm{PtCl} \text { mole } \\
\text { per } 1,000 \mathrm{~g} \\
\mathrm{H}_{2} \mathrm{O}\end{array}$ & $\begin{array}{c}\text { Total con- } \\
\text { centration of } \\
\text { Pt salts }\end{array}$ & $\begin{array}{c}\text { Measured } \\
\text { emf (volt) }\end{array}$ \\
\cline { 2 - 4 } 0.000483 & 0.000520 & 0.001003 & \\
.000252 & .000752 & .001004 & .45852 \\
.001956 & .000555 & .002511 & .47200 \\
.001248 & .001251 & .002499 & .44095 \\
.000500 & .002009 & .002509 & .47620 \\
.002488 & .002511 & .004999 & .45849 \\
.003957 & .001017 & .004974 & .44044 \\
.008999 & .001026 & .010025 & .43034 \\
.007504 & .002483 & .009987 & .44456 \\
\hline
\end{tabular}

In Table 2 are given the values of $E+(R T / 2 F) \log _{\mathbf{e}}\left(P t C l_{4}\right) /\left(P t C l_{8}\right)$ at round concentrations, together with the corresponding values of the square root of the ionic strength of each solution.

TABLE 2.-Emf and ionic strength data calculated for round concentrations

\begin{tabular}{|c|c|c|}
\hline $\begin{array}{l}\text { Total concen- } \\
\text { tration of } \mathrm{Pt} \\
\text { salts (Pt) in } 0.1 \\
N K C l \text { solution } \\
\text { mole per 1,000 } \\
\mathrm{g} \mathrm{H}_{2} \mathrm{O}\end{array}$ & $\frac{\sqrt{\sigma}}{\sqrt{0.1+3(P t)}}$ & $E+\frac{R T}{2 F} \log _{e} \frac{\left(P t C l_{4}--\right)}{\left(\mathrm{PtCl}_{6}\right)^{--}}$ \\
\hline $\begin{array}{l}0.001 \\
.0025 \\
.005 \\
.01\end{array}$ & $\begin{array}{r}0.321 \\
.328 \\
.339 \\
.361\end{array}$ & $\begin{array}{r}0.4575 \\
.4578 \\
.4584 \\
.4592\end{array}$ \\
\hline
\end{tabular}




\section{DISCUSSION}

For very dilute solutions of electrolytes the activity coefficient, $\gamma$, of an ion of valence $z$ is given by the equation

$$
\log _{10} \gamma=0.52 z^{2} \sqrt{\sigma}
$$

where $\sigma$ is the ionic strength. If this equation were valid for the range of concentrations used in this investigation the activity coefficients of the chloroplatinate and the chloroplatinite would be equal. and cancel each other and the value of $E_{0}$ calculated from equation (1) should be the same for each measurement. However, the total concentration of every solution used was greater than tenth normal and the values of $E_{0}$ from equation (1), or of $E^{\prime}$ from equation (3), show a tendency to increase with increasing ionic strength, as is seen in Table 2. For this reason, the values of $E^{\prime}$ were plotted, as shown in Figure 2, against the square root of the ionic strength, in order to extrapolate for the value of $E_{0}$ in tenth normal potassium chloride

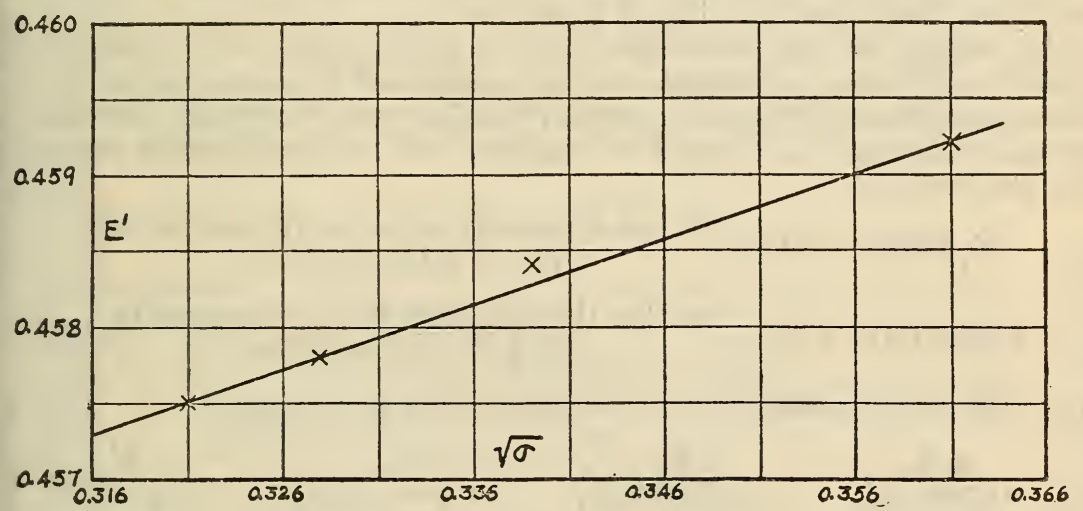

Figure 2.-Plot of $E^{\prime}$ against $\sqrt{\sigma}$

solution. The value thus obtained, $E_{0}=0.4573$ v., is the electromotive force of the cell

$$
\mathrm{Hg}\left|\mathrm{HgCl}, \mathrm{KCl}(0.1) \underset{\mathrm{PtCl}_{6}^{--}(A)}{\mathrm{PtCl}_{4}^{--}(A)}\right| \mathrm{Pt} \text { at } 35^{\circ}
$$

in which $(A)$ is the activity of the complex platinum ions in the thermodynamic environment of pure 0.1 normal potassium chloride solution. This should not be confused with the "standard" or "molal" electrode potential, since the latter is ordinarily restricted to an environment of pure water.

Since this work and that of Miller and Terrey are the only investigations that have been carried out on this electrode system, a comparison of results is of interest. The comparison, however, is possible for only one of their measurements where they used the cell

$$
\mathrm{Hg}|\mathrm{HgCl}, \mathrm{NaCl}(1 \mathrm{~N})| \begin{aligned}
& \mathrm{NaCl}^{2}(0.1 \mathrm{~N}) \\
& \mathrm{PtCl}_{4}^{-2}(0.0009987) \\
& \mathrm{PtCl}_{6}^{--(0.001462)}
\end{aligned} \mid \mathrm{Pt} \text { at } 25^{\circ}
$$

In this cell the total concentration of platinum salts is 0.00246 molal and the thermodynamic environment is tenth normal sodium chloride solution. The conditions are, therefore, comparable with those 
under which the data given in the second row of Table 2 were obtained. $E$ (measured) for this cell is $0.5058 \mathrm{v}$. The liquid junction potential is $0.0105 \mathrm{v}$. and $(R T / 2 F) \log _{\mathrm{e}}\left(\mathrm{PtCl}_{4}^{-}\right) /\left(\mathrm{PtCl}_{6}{ }^{-}\right)=-0.0049$. We, therefore, have $E^{\prime}=0.5058+0.0105-0.0049=0.5114 \quad$ v. Taking the electrode potential of the normal calomel electrode with sodium chloride to be the same as with potassium chloride $(0.2805 \mathrm{v} .)^{6}$ the corrected potential at the platinum electrode is $0.7919 \mathrm{v}$. Miller and Terrey found $21,720 \mathrm{cal}$. for the heat evolved during the reaction $2 \mathrm{Hg}+\mathrm{PtCl}_{6}{ }^{-}=2 \mathrm{HgCl}+\mathrm{PtCl}_{4}{ }^{-}$by measuring the temperature coeffcient of electromotive force of the cell. Using this value in the GibbsHelmholtz equation we find $E^{\prime}=0.4582$ for our cell at $25^{\circ}$ with a total platinum molality of 0.0025 in 0.1 normal potassium chloride. The value for the tenth normal calomel electrode ${ }^{6}$ is $0.3334 \mathrm{v}$. and, therefore, the corrected potential at the platinum electrode is $0.7916 \mathrm{v}$., which compares very favorably with the value 0.7919 , obtained above from the work of Miller and Terrey. This favorable agreement depends largely on the choice of values for the potentials of the reference electrodes and the liquid junction.

By means of the equations $\Delta Z_{0}=-E_{0} N F, \Delta Z_{0}=\Delta H_{0}-T \Delta S_{0}$, and $E_{0} N F=R T \log _{e} K$, in which $\Delta Z_{0}, \Delta H_{0}, \Delta S_{0}$, and $K$ are, respectively, the change in thermodynamic potential (Gibbs's zeta function), the change in heat content, the change in entropy, and the equilibrium constant for the reaction

$$
\left.\begin{array}{c}
2 \mathrm{Hg}(\mathrm{l})+\mathrm{PtCl}_{6}-\left\{\begin{array}{l}
\text { in the thermodynamic environment of } \\
0.1 \mathrm{~N} \mathrm{KCl} \text { solution }
\end{array}\right.
\end{array}\right\}
$$

the following values of these properties can be obtained
$\Delta Z_{0}$
$\triangle H_{0}$
$\Delta S_{0}$
$K$

$-21,100$ cal.

$$
-21,700 \mathrm{cal} .{ }^{7} \quad-1.9 \mathrm{cal} . / \mathrm{deg} \text {. }
$$

\section{SUMMARY}

The electromotive force of the cell

$$
-\mathrm{Hg}\left|\mathrm{HgCl}, \operatorname{KCl}(0.1), \begin{array}{l}
\mathrm{KCl}(0.1) \\
\mathrm{K}_{2} \mathrm{PtCl}_{4}\left(m_{1}\right) \\
\mathrm{K}_{2} \mathrm{PtCl}_{6}\left(m_{2}\right)
\end{array}\right| \mathrm{Pt}+\text { at } 35^{\circ}
$$

where $m_{1}$ and $m_{2}$ are small compared with 0.1 has been measured for values of $\left(m_{1}+m_{2}\right)$ ranging from 0.001 to 0.01 . The equation

$$
\mathrm{E}=E_{0}-(R T / 2 F) \log _{\mathrm{e}} m_{1} / m_{2}+k \sqrt{\sigma}
$$

in which $k$ is a constant and $\sigma$ is the ionic strength of the solution, represents the experimental data and gives a value of $0.4573 \mathrm{v}$. for $E_{0}$ in tenth normal potassium chloride solution. From this value of $E_{0}$ and the known change in heat content accompanying the cell reaction, the corresponding change in thermodynamic potential, change in entropy and the equilibrium constant were calculated.

Washington, February 20, 1930. 